\title{
Stress Level during Thesis Writing in Pandemic Covid-19 among Midwife Students at Universitas Airlangga Surabaya
}

\author{
Melati Nur Ramadana, Azimatul Karimah ${ }^{\mathrm{b}}$, Astika Gita Ningrumª \\ a azimatul.karimah@fk.unair.ac.id

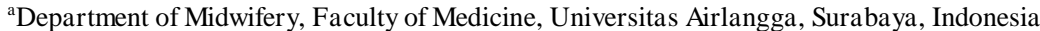 \\ ${ }^{b}$ Department of Psychiatry, Faculty of Medicine, Universitas Airlangga, Surabaya, Indonesia
}

\begin{abstract}
Background: There are many obstacles and difficulties experienced by students while working on their thesis so that it can cause stress. Aims: To describe of stress level among midwife students during thesis writing in pandemic covid-19 at Universitas Airlangga Surabaya year batch 2018. Methods: This study was descriptive cross sectional research on 38 midwifery students. The data was taken on March - October 2021 using DASS 21 modified into google form. Results: The results showed that most of the respondents, namely 28 people $(73.7 \%)$ were 21 years old and all respondents were female. The majority of respondents, namely 23 people $(60.5 \%)$ experienced stress at normal level. There were 15 $(39,5 \%)$ respondents experienced stress at any level, and mostly were mild and moderate $(13,2 \%)$ respectively. Five students reported severe and very severe stress. Conclusions: The majority of Midwife Students at Universitas Airlangga Surabaya experienced stress at normal level and others experienced stress at any level due thesis writing period. This study needs further exploration whether thesis is the only stressor among midwifery students.
\end{abstract}

Keywords: Midwifery; stress level; thesis

\section{Introduction}

A thesis or final project is one of the requirements for students to obtain a graduate degree in college and to test students' abilities in researching problems found related to their scientific fields (Wardi and Ifdil, 2016; Susane, 2017; Permatasari, Arifin and Padilah, 2020; Ramanda and Sagita, 2020). However, there are many obstacles and difficulties experienced by students in the process of working on their thesis, both from within the students themselves (such as the ability to manage time, laziness, difficulty finding titles or themes, lack of understanding of the problem under study, ability to write and compose sentences, difficulty finding references and reading materials, repeated revisions, the assumption that they do not have experience in compiling final assignments, and etc.) and from the environment (such as limited research time, difficult to contact thesis supervisors, and the Covid-19 pandemic) (Wardi and Ifdil, 2016; Aulia and Panjaitan, 2019; Rosyad, 2019; Permatasari, Arifin and Padilah, 2020; Ramanda and Sagita, 2020; Winasis, Kurniawan and Vioneery, 2021). For example, the current obstacle is the Covid-19 pandemic and the SE of the Dean of the Faculty of Medicine, Universitas Airlangga regarding Student Publication Obligations. 
The Covid-19 pandemic has had an impact in various sectors, one of which is in the education sector which creates various difficulties for students in the process of working on their thesis. Restrictions on physical meetings with supervisors and difficulties in taking data directly to schools or other places are some of the problems faced by students in the process of completing their final assignment (Damayanti, 2020; Permatasari, Arifin and Padilah, 2020). In addition, the announcement letter of the Dean of the Faculty of Medicine, Universitas Airlangga on March 17, 2021, regarding Student Publication Obligations which states that students must publish up to the "accepted" stage, is the latest challenge faced by students.

The Midwifery Study Program is one of the Study Programs at Universitas Airlangga located within the Faculty of Medicine, on campus A UNAIR. The educational process in this study program consists of two stages, namely the undergraduate stage and the professional stage (Midwifery Study Programme Faculty of Medicine, 2016). Based on data from the Secretariat of the Unair Midwifery Study Program regarding the speed of student graduation, from 45 regular students year batch 2016, only $11.1 \%$ students attended the graduation on time, $82.2 \%$ students took the next stage of graduation, and $6.7 \%$ students did not graduate until now.

Every individual has a different level of stress. One of the factors that can cause differences in stress levels in each individual is the coping mechanism (Rahmayani, Liza and Syah, 2019). Stress disorders usually appear slowly, are not clear when it started, and often go unnoticed. Potter and Perry (2006) categorizes stress levels into mild, moderate, and severe stress. While based on the DASS 21 questionnaire, stress levels were categorized into normal, mild, moderate, severe, and very severe.

Based on the description above, the researchers are interested in researching the Stress Level during Thesis Writing in Pandemic Covid-19 among Midwife Students at Universitas Airlangga Surabaya.

\section{Method}

The research design used was descriptive quantitative research with a cross sectional approach. The population in this study is 48 students of the midwife students at Universitas Airlangga Surabaya year batch 2018. Sampling using stratified random sampling technique. The sample size was calculated using the formula and the results obtained were 38 respondents.

Data was collected in March - October 2021 using DASS-21 (Depression Anxiety and Stress Scale) questionnaire on google form from respondents. The results of the questionnaire answers are then processed by editing, coding, data entry, cleaning, and tabulation. 


\section{Result}

Table 1. Characteristics of Respondents

\begin{tabular}{lll}
\hline Age (year) & $\mathrm{N}$ & $\%$ \\
\hline 20 & 2 & 5.3 \\
21 & 28 & 73.7 \\
22 & 8 & 21.1 \\
\hline
\end{tabular}

Table 1 shows that the majority of respondents aged 21 years were 28 people $(73.7 \%)$, respondents aged 20 years were 2 people $(5.3 \%)$, and respondents aged 22 years were 8 people $(21.1 \%)$. All respondents were female $(100 \%)$.

Table 2. Frequency distribution of stress level

\begin{tabular}{lll}
\hline Stress Level & $\mathrm{N}$ & $\%$ \\
\hline Normal & 23 & 60.5 \\
Mild & 5 & 13.2 \\
Moderate & 5 & 13.2 \\
Severe & 4 & 10.5 \\
Very Severe & 1 & 2.6 \\
\hline
\end{tabular}

Table 3 shows that the majority of respondents, namely 23 people $(60.5 \%)$ experienced stress at normal level. There were $15(39,5 \%)$ respondents experienced stress at any level, and mostly were mild and moderate $(13.2 \%)$ respectively. Five students reported severe and very severe stress.

\section{Discussion}

College students are categorized in the age range of 18-25 years according to their stage of development. This stage is from late adolescence to early adulthood. At this age, there is consolidation in the establishment of life and self-discovery, already understanding and being able to distinguish between good things to do and bad things to avoid. (Yusuf, 2012). In addition, Mussen, Conger, and Kagan (in Indarwati, 2018) say that this period (the age of being a college student) becomes a period of life where the peak for obtaining and using the knowledge efficiently occurs. This is because during this period, the brain experiences perfect growth and the nervous system in charge of processing information develops rapidly so that students can formulate strategic plans and have the ability to make decisions. A study by Winasis, Kurniawan and Vioneery (2021) on the level of depression in diploma III nursing students during thesis writing, showed that most of the respondents 
were 21 years old with a total of 41 people (57.7\%). Another study by Amalia (2019) also showed that the majority of final year midwife students at the Poltekkes Surabaya were 21 years old.

According to Ikatan Bidan Indonesia (IBI), a midwife is a woman who graduated from midwifery education recognized by the government and professional organizations in the territory of the Republic of Indonesia and has the competence and qualifications to be registered, certified and/or legally licensed to practice midwifery (IBI, 2016). A study by Khajehei et al. (2011) also shows that the sample was entirely female. However, the study by Avci and Kaya (2021) showed different results that $84.5 \%$ of the students were female and the others were male. Theory by Kaplan \& Sadock (in Ambarwati, Pinilih and Astuti, 2017) says that women are twice as likely to experience stress as men. This is due to hormonal differences and differences in psychosocial stressors between men and women. This research is also supported by data from the Indonesian Psychiatric Association (IPA) during April-August 2020 which showed that as many as 64.8\% of 4010 respondents experienced psychological problems and the incidence was higher in women, namely 71\% (PDSKJI, 2020). A study by Nasrani and Purnawati (2015) shows that women tend to experience higher stress levels than men in terms of mild, moderate, and severe stress levels. There are differences in the response between women and men when facing a conflict where the female brain has negative alertness that triggers the emergence of negative hormones causing stress, anxiety, and fear. Meanwhile, men generally enjoy conflict and think that conflict can provide a positive boost. So it can be said that when women are under pressure, they are generally more prone to stress.

This research is in line with the results of research conducted by Rosyad (2019) where most (59.3\%) the stress level of students who are writing their thesis is in the normal category, $18.5 \%$ mild stress, $11.1 \%$ moderate stress, $7.4 \%$ severe stress, and 3.7\% very severe stress. The other study by Rezaei, Falahati and Beheshtizadeh (2020) with 70 participants shows that approximately $56 \%$ of the midwifery students perceived a high level of stress. In addition, a study by Aulia and Panjaitan (2019) on students of the Faculty of Nursing, Universitas Indonesia who are currently completing their thesis, showed that 77 respondents $(71.3 \%)$ experienced moderate stress, 15 respondents (13.9\%) experienced mild stress, and 16 respondents $(14.8 \%)$ experienced severe stress. The average level of normal and mild stress is experienced by students who are writing a thesis because during the period of development as a student there is a process of brain growth that reaches its peak. This is because during this period the brain reaches perfect growth and the nervous system in charge of processing information develops rapidly so that students have the ability to formulate strategic plans and make the right decisions (Wahyuni and Setyowati, 2020).

College students are faced with various conditions that can trigger stress. In carrying out lecture activities, students are faced with various problems, both from within the students themselves and from the 
environment. The occurrence of rapid intellectual and cognitive development makes students able to manage and cope with the stress they experience so that stress does not become severe or cause negative consequences for themselves.

\section{Conclusion}

Based on the results of research on the stress level during thesis writing in pandemic Covid-19 among midwife students at Universitas Airlangga Surabaya can be concluded that the majority of Midwife Students at Universitas Airlangga Surabaya experienced stress at normal level and others experienced stress at any level due thesis writing period. This study needs further exploration whether thesis is the only stressor among midwifery students.

By knowing the conditions and stress levels earlier, college students are expected to be able to manage stress as early as possible so that the stress experienced does not worsen and cause negative impacts for students. The head of the Midwifery Study Program Faculty of Medicine Universitas Airlangga Surabaya can also provide counseling to students who are experiencing stress, especially academic stress.

\section{Acknowledgements}

The author would like to thank the supervisor who has guided me in this research and the head of the Midwifery Study Program Faculty of Medicine Universitas Airlangga Surabaya who has permitted me to conduct this research.

\section{References}

Amalia, A. (2019). Hubungan Antara Emotional Well Being dengan Stres Akademik pada Mahasiswa Kebidanan [Universitas Islam Negeri Sunan Ampel].

Ambarwati, P. D., Pinilih, S. S. and Astuti, R. T. (2017) 'Gambaran Tingkat Stres Mahasiswa', Jurnal Keperawatan Jiwa, 5(1), pp. 4047.

Aulia, S. and Panjaitan, R. U. (2019) 'Kesejahteraan Psikologis dan Tingkat Stres pada Mahasiswa Tingkat Akhir', Jurnal Keperawatan Jiwa, 7(2), pp. 127-134.

Avci, N. and Kaya, G. (2021) 'the Relationship of Learned Resourcefulness with Self-Leadership Skills: A Study with Nurse and Midwife Students', Nurse Education Today, 107.

Damayanti, R. (2020) Analisis Kesulitan Mahasiswa Menyelesaikan Skripsi pada Situasi Pandemi Covid 19. Universitas Muhammadiyah Sumatera Utara.

IBI (2016) Definisi. Available at: www.ibi.or.id

Indarwati (2018) Gambaran Stres Mahasiswa Tingkat Akhir dalam Penyusunan Skripsi di Fakultas Kedokteran dan Ilmu Kesehatan UIN Alauddin Makassar. UIN Alauddin Makassar.

Khajehei, M. et al. (2011) 'The Genesis and Consequences of Stress among Midwifery Students', British Journal of Midwifery, 19(6), pp. 379-385.

Midwifery Study Programme Faculty of Medicine (2016) Panduan Pendidikan. Available at: www.bidan.fk.unair.ac.id

Nasrani, L. and Purnawati, S. (2015) 'Perbedaan Tingkat Stres antara Laki-Laki dan Perempuan pada Peserta Yoga di Kota Denpasar', EJurnal Medika Udayana, 4(12). 
PDSKJI (2020) 5 Bulan Pandemi Covid-19 di Indonesia. Available at: www.pdskji.org

Permatasari, R., Arifin, M. and Padilah, R. (2020) 'Studi Deskriptif Dampak Psikologis Mahasiswa Program Studi Bimbingan dan Konseling Universitas PGRI Banyuwangi dalam Penyusunan Skripsi di Masa Pandemi Covid-19', Jurnal Bina Ilmu Cendekia, 2(1), pp. 127-141.

Potter and Perry (2006) Buku Ajar Fundamental Keperawatan: Konsep, Proses, dan Praktik E/4, vol 2. Jakarta: EGC.

Rahmayani, R. D., Liza, R. G. and Syah, N. A. (2019) 'Gambaran Tingkat Stres Berdasarkan Stressor pada Mahasiswa Kedokteran Tahun Pertama Program Studi Profesi Dokter Fakultas Kedokteran Universitas Andalas Angkatan 2017', Jurnal Kesehatan Andalas, 8(1), pp. 103-111.

Ramanda, P. and Sagita, D. D. (2020) 'Stres Akademik Mahasiswa dalam Menyusun Skripsi di Masa Pandemi Covid-19', Jurnal Kopasta, 7(2), pp. 94-100.

Rezaei, B., Falahati, J. and Beheshtizadeh, R. (2020) 'Stress, Stressors and Related Factors in Clinical Learning of Midwifery Students in Iran: A Cross Sectional Study', BMC Medical Education, 20(1), pp. 1-10.

Rosyad, Y. S. (2019) 'Tingkat Stres Mahasiswa Sekolah Tinggi Ilmu Kesehatan Yogyakarta dalam Menyusun Skripsi Tahun Akademik 2018/2019', Cahaya Pendidikan, 5(1), pp. 56-64.

Susane, I. M. A. (2017) Hubungan Tingkat Stres terhadap Motivasi Mahasiswa dalam Menyelesaikan Skripsi pada Mahasiswa Tingkat Akhir di Fakultas Kedokteran Universitas Lampung. Universitas Lampung.

Wahyuni, S. and Setyowati, R. (2020) 'Gambaran Stress Mahasiswa Tingkat Akhir dalam Penyusunan KTI Ditengah Wabah Covid 19 dan Sistem Lockdown yang Diberlakukan di Kampus Akper YPIB Majalengka', Jurnal Akper YPIB Majalengka, 6(12), pp. $1-14$.

Wardi, R. and Ifdil (2016) 'Stress Conditions in Students Completing Thesis', GUIDENA: Jurnal Ilmu Pendidikan, Psikologi, Bimbingan dan Konseling, 6(2), pp. 190-194.

Winasis, G. P., Kurniawan, S. T. and Vioneery, D. (2021) Gambaran Tingkat Depresi Mahasiswa Diploma III Keperawatan dalam Menjalani Tugas Akhir Karya Tulis Ilmiah (KTI) di Universitas Kusuma Husada Surakarta.

Yusuf, S. (2012) Psikologi Perkembangan Remaja dan Dewasa. Bandung: PT. Remaja Rosda. 